\title{
The Transformative Educative Prospects of Flexible Learning Environments
}

New Zealand Journal of Teachers' Work, Volume 12, Issue 1, 9-13, 2015

\author{
LEON BENADE \\ School of Education \\ Auckland University of Technology
}

Over the past five years or so, the New Zealand Ministry of Education has committed itself to a programme of providing significantly upgraded and modernised buildings. As it notes:

\begin{abstract}
We want all schools to have vibrant, well connected, innovative learning environments (ILE) that encourage and support many different types of learning.
\end{abstract}

An ILE is the complete physical, social and pedagogical context in which learning can occur. We used to refer to these as modern learning environments (MLE). An ILE is capable of evolving and adapting as educational practices evolve and change. (2015), "Flexible learning spaces in schools")

What's in a name? The title of my piece refers to 'flexible learning environments'. The Ministry of Education started out calling these 'modern learning environments' (MLE) and now, more recently, 'innovative learning environments' (ILE). The lived reality is interesting, as the short-hand preference of many teachers, principals and others is to 'MLE', and it may be some time before the Ministry of Education succeeds in shifting this usage to 'ILE'. The term 'flexible learning environments' is one I prefer. The use of the terminology of 'flexibility' is not unusual-see the State of Victoria (2011, "Making the most of flexible learning spaces"), and indeed, the title of the Ministry of Education reference above (2015, "Flexible learning spaces in schools"). There is another reason I shy away from 'modern', because in academic contexts, 'modern' is related to 'modernity', and this is a perspective associated with such notions as Enlightenment progress, rationality and universal narratives. The postmodern (whether one accepts its tenets or not), is a position that is much more pertinent to descriptions and analyses of current times, and is best understood in terms of Lyotard's (1993) incredulity towards metanarratives. I will return to this point later.

Consider, however, the common usage of 'modern'. According to this usage, 'modern' can also mean 'contemporary' or 'new', while 'innovative' could also mean 'ground-breaking' or 'novel'. In both cases, these terms seem to apply to the buildings, technology and trappings of these environments (and this 
is the meaning implied in the Ministry quote above). On the other hand, 'flexible' can mean 'supple', 'lithe' and 'adaptable'. Clearly, these terms do not apply to a building or technology, but rather to practices or personality traits. This is the primary difference in approach I would like to highlight-to focus on the practices within a space, rather than the space itself. I will return to this point later as well.

Where did the idea come from? The motivation behind building to the new designs has several sources-one could look to global drivers such as the Organisation for Economic Cooperation and Development (OECD) Definition and Selection of Competencies: Theoretical and Conceptual Foundations (DeSeCo) programme (2003), leading countries around the world to provide curricula designed to prepare young people for an uncertain 21st century economic future. This rhetoric of ' $21^{\text {st }}$-century learning' is another driver. The rhetoric claims that learning must prepare school-leavers for the fluidity, unpredictability and complexity of a complex and dynamic world deeply influenced by globalisation and the revolution in digital technology (see, for example, Beetham \& Sharpe, 2013; Bolstad \& Gilbert, 2012; Loveless \& Williamson, 2013). And then there is the design perspective-schools' architect, Prakash Nair (2011), boldly proposed, "the classroom has been obsolete for several decades. That's not just my opinion. It's established science" (p. 1). Nair's remedy (and that of other designers, such as Fisher, 2005, and Tanner, 2009 ) is to redesign learning spaces that will bring about $21^{\text {st }}$ century teaching and learning practices. It may come as little surprise, therefore, that the New Zealand Ministry of Education has been significantly influenced in these designs by the work of designers, Fielding Nair International (http://www.fieldingnair.com).

Thus, an increasing number of New Zealand classrooms and schools present these new technology-rich flexible learning spaces, characterised by large open spaces, permeable boundaries and diverse furnishings emphasising student comfort health and flexibility. Open design encourages flexibility in learning and teaching (Chapman, Randell-Moon, Campbell \& Drew, 2014), and allows collaborative, team teaching.

Ironically, to return to the modern vs postmodern ideas I mentioned at the start, it could be suggested that the ideas about the $21^{\text {st }}$ century seem to acknowledge the postmodern (there's no longer one, fixed, stable narrative), while the response of the Ministry of Education is typically 'modern', by presenting one solution to address the educational requirements of the fluidity and complexity of the $21^{\text {st }}$ century.

According to a recent newspaper report in New Zealand's Sunday Star Times (Walters, 2015), some (named) principals of certain 'top' schools in Auckland objected to the new learning environment designs preferred by the Ministry of Education. Flexible learning environments are referred to in the report as "extreme examples of the modern classrooms" (2015a) citing David Hodge, Principal of Rangitoto College, for whom these learning spaces are "an open plan barn". Their transparency is said to encourage distraction, making learning impossible, while students are left "to their own devices" (2015a).

Earlier in the year, a New Zealand Herald article, under the headline, "Grammar eschews beanbag lessons in \$6m classroom upgrade" (Johnston, 2015) was followed a few days later by a John Morris opinion piece, also in the New Zealand Herald, in which he congratulated his old school for avoiding 'one 
size fits all' classrooms (Morris, 2015). The building of these classroom spaces, according to Morris, is a 'fad', which both he and Auckland Grammar Principal, Tim O'Connor, believed was typified by such unconventional school furniture as beanbags.

To remain "at or near the top of the ladder" (Walters, 2015), the schools mentioned in the reports would not risk the chance of a failed 'experiment'. In 'top' schools instead, the emphasis would remain on traditional teaching, including 40-minute periods and teacher control.

As an aside, one could suggest a further ironic tension is evident between the 'modern' and 'postmodern': the principals cited in the reports prefer the traditional, known and certain paths schools have trod for decades (modern); yet they cry foul at the prospect of all schools being dragooned into accepting a common design for all schools (also modern!). Yet it is this design, with its permeable spaces and fluid boundaries, allowing collaborative learning and responsive pedagogy to develop, which is promoted as a more appropriate space to develop skills required for the $21^{\text {st }}$ century.

Ironies and twists aside, all three articles do make some telling points on behalf of these highly-respected educational leaders - the teacher makes all the difference, space does not; there is still a need for teachers to teach; and schools that are self-governing should have some voice over building refurbishment.

On the other hand, some wild and unsubstantiated comments are made in these reports that do not stack up against the evidence of the classroom practice I have observed in flexible learning environments in the course of my own research. Teachers do not abdicate their responsibility for teaching in the flexible learning environments I have observed. Teachers do provide direct instruction. Certainly, students (primary and secondary) do get to make choices about their learning routines and curriculum, but all under the watchful eye of their very well planned teachers.

The point about flexible learning environments-completely lost, it seems to me, in these media articles, is that a holistic understanding is required. True, it is not only about the space. It is about the flexibility of practice offered by large, differently designed spaces. It is also about the walls, and their role in learning; about furniture that does not lock students down to a single place for the time they are in that space; about flexible approaches to timetabling; about the ICT and mobile technology that can be used anywhere in the space to support learning; about the more efficient use of resources, like teacher aides; about the role played by teachers in preparing for complex learning options; and, ultimately, about the development of skills, aptitudes, attitudes and, yes, the knowledge independent students can acquire when they are not spoon-fed in tiny rigid boxes. And this, it seems to me, points to a very important signflexible, shared spaces have the potential to transform education and the educational experience. 


\section{REFERENCES}

Beetham, H., \& Sharpe, R. (Eds). (2013). Rethinking pedagogy for a digital age: Designing for 21st century learning (2nd ed.). New York, NY: Routledge.

Bolstad, R. \& Gilbert, J. with McDowall, S., Bull, A., Boyd, S. and Hipkins, R. (2012). Supporting Future-Oriented Learning and Teaching: A New Zealand perspective. Report prepared for the Ministry of Education. Wellington: New Zealand Council for Educational Research and Ministry of Education. Retrieved August 8, 2015, from http://www.educationcounts.govt.nz/publications/schooling/109306

Chapman, A., Randell-Moon, H., Campbell, M. \& Drew, C. (2014). Students in space: Student practices in non-traditional classrooms. Global Studies of Childhood 4(1), 39-48. doi: 10.2304/gsch.2014.4.1.39

Fielding Nair International. (2015). Home. Accessed 12 August 2015, from http://www.fieldingnair.com

Fisher, K. (2005). Research into identifying effective learning environments. Retrieved from http://www.oecd.org/edu/innovationeducation/37905387.pdf

Johnston, K. (2015, May 11). Grammar eschews beanbag lessons in $\$ 6 \mathrm{~m}$ classroom upgrade. New Zealand Herald. Retrieved from http://www.nzherald.co.nz/nz/news/article.cfm?c id=1\&objectid=1144645 1

Loveless, A., \& Williamson, B. (2013). Learning identities in a digital age: Rethinking creativity, education and technology. New York, NY: Routledge.

Lyotard, J-F. (1993). The postmodern condition: A report on knowledge (G. Bennington \& B. Massumi, Trans.). Minneapolis, MN: University of Minnesota Press.

Ministry of Education (MOE). (2015). Flexible learning spaces in schools. $\begin{array}{lllll}\text { Retrieved on } & 12 & \text { August } & 2015 & \text { from }\end{array}$ http://www.education.govt.nz/school/property/state-schools/designstandards/flexible-learning-spaces/

Morris, J. (2015, May 15). Grammar wise to steer clear of the 'one size fits all' classrooms. New Zealand Herald. Retrieved from http://www.nzherald.co.nz/nz/news/article.cfm?c id=1\&objectid=1144881 $\underline{6}$

Nair, P. (2011). The classroom is obsolete: It's time for something new. Education Week. Retrieved from http://www.fieldingnair.com/index.php/publications/ 
Organisation for Economic Cooperation and Development (OECD). (2003). Definition and selection of competencies: Theoretical and conceptual foundations (DeSeCo): Summary of the Final Report. Retrieved 17 August 2015 from http://www.oecd.org/education/skills-beyondschool/definitionandselectionofcompetenciesdeseco.htm

State of Victoria (Department of Education and Early Childhood Development). (2011). Making the most of flexible learning spaces: A guide for principals and teachers. Retrieved 27 August 2015 from http://www.education.vic.gov.au/

Tanner, C. K. (2009). Effects of school design on student outcomes. Journal of Educational Administration, 47, 376-394. doi:10.1108/09578230910955809

Walters, L. (2015, October, 18). Top schools give multi-million dollar classrooms a fail grade. Sunday Star Times. Retrieved from http://www.stuff.co.nz/national/education/73042309/Top-schools-givemulti-million-dollar-classrooms-a-fail-grade 